THE WABASH CENTER

JOURNAL ON TEACHING
BOOK REVIEW

\section{Theology as a Way of Life: On Teaching and Learning the Christian Faith}

\author{
Adam Neder \\ Grand Rapids, MI: Baker Academic Press, 2019 \\ (xi +158 pages, ISBN 978-0-8010-9878-9, \$18.99)
}

Reviewed By

Daniel Orlando Álvarez

Pentecostal Theological Seminary
Adam Neder's book is a refreshing look at theological education by a systematic theologian. As someone who teaches systematic theology, this book is appealing. I have wrestled with questions about how this academic pursuit shapes and forms the students I teach. This is a very approachable and easy-to-read book that asks questions that challenge our notions of formation in the theological discipline. Being in my early

career in teaching, I find this book to be welcome as I am developing how I view my career, pedagogy, and theological vocation. As a Latinx theologian, I also appreciate Neder's inclusion of relatable examples and illustrations, such as Andrés Iniesta and FC Barcelona (although I am a Real Madrid fan).

Neder's book consists of an introduction and five chapters. In the introduction, Neder gives some details about his own journey of how he encountered good pedagogy and bad pedagogy in his training. He also shares about his experiences teaching at a university for sixteen years. This book is a result of Neder's struggle to formulate a theological and spiritual understanding of teaching (1). This is an important task as there are many books about teaching and liberal arts education, but there are few from contemporary theologians about the art of teaching Christian theology (2). For him, one must have a theological vision of what it means to teach Christian theology well.

In the next five chapters Neder develops his vision using five themes: Identity, Knowledge, Ethos, Danger, and Conversation. These themes are important foundational ideas about the pedagogical task, especially as related to formation. In the chapter on Identity Neder describes how every student is essentially defined by God's love for them in Christ and not by their opposition to God's love. Pedagogy is relational and reconciliatory. This allows the classroom to take on a unique dynamic. The chapter on Knowledge wrestles with what it means to know God. The tension here is about mere head knowledge versus integrating that knowledge into one's life. In the following chapter, Ethos, Neder explores a theologian's credibility and how theologians can build a rapport with her or his students. In the penultimate chapter, Danger, Neder discusses how theology is a safe but dangerous discipline for students. The final chapter, Conversation, Neder encourages the reader to cultivate conversations in the classroom to create a dialogical culture.

Although a bit heavy on content from Barth (Neder's specialization), I think this text does good for teachers of religion in both undergraduate Christian universities and seminaries. I think educators across religious disciplines will benefit from reading this text. It may prod some to leave their comfort zones. For others, it may confirm a hunch they have had about their vocation. Although it is firmly from a Christian point of view, those of other religions may also benefit from it as they may face similar dynamics within their own traditions. 